OPEN ACCESS

Edited by:

Jessica Tyler,

Cornell University, United States

Reviewed by:

Ulrike Resch,

Medical University of Vienna, Austria

Paschalia Pantazi,

Imperial College London,

United Kingdom

*Correspondence:

Ling Zhang

Zhling312@163.com

Wenpei Xiang

wpxiang2010@gmail.com

${ }^{t}$ These authors have contributed

equally to this work

Specialty section:

This article was submitted to

Cellular Biochemistry,

a section of the journal

Frontiers in Cell and Developmental

Biology

Received: 28 June 2020

Accepted: 27 August 2020

Published: 17 September 2020

Citation:

Liu Y, Shen Q, Zhang L and Xiang W (2020) Extracellular Vesicles: Recent Developments in Aging

and Reproductive Diseases.

Front. Cell Dev. Biol. 8:577084. doi: $10.3389 /$ fcell.2020.577084

\section{Extracellular Vesicles: Recent Developments in Aging and Reproductive Diseases}

\author{
Yu Liu, Qiuzi Shen, Ling Zhang ${ }^{\star t}$ and Wenpei Xiang*t \\ Institute of Reproductive Health and Center for Reproductive Medicine, Tongji Medical College, Huazhong University \\ of Science and Technology, Wuhan, China
}

Extracellular vesicles (EVs), present in cell culture media and several body fluids, play a prominent role in intercellular communication under physiological and pathological conditions. We performed a systematic literature search to review evidence regarding the existence, composition, and release of different EVs, as well as the biomarkers, cargos, and separation methods. We also reviewed the potential of EVs to transport cargos and alter the function and phenotype of recipient cells associated with aging and reproductive diseases, including polycystic ovary syndrome and endometriosis. In aging, EVs promote inflammatory reactions and offsetting the occurrence of aging. In the polycystic ovary syndrome and endometriosis, EVs and their cargos are involved in the occurrence of diseases, therapeutic strategies, and perform as non-invasive biomarkers. As the study of EVs is still in the early stages, it is not surprising that most of the current literature only describes their possible roles.

Keywords: extracellular vesicles, isolation, aging, polycystic ovary syndrome, endometriosis

\section{INTRODUCTION}

Intercellular communication has been shown to play an essential role in diverse physiological processes, including cell proliferation, development, and differentiation. Published literature in recent years has revealed a new mechanism of intercellular communication, namely via the release of extracellular vesicles (EVs). Classically, intercellular communication includes endocrine, paracrine, and autocrine or intercellular gap junctions, a kind of direct cell-cell contact, and secreted some factors. In the group of secreted factors, we will focus here on the roles of EVs. EVs secreted outside of the cell can serve as vehicles for the transport of cargo to recipient cells (Raposo and Stoorvogel, 2013). EVs display a diverse range of sizes and are present in cell culture media (under both normal and pathological conditions) and several body fluids (Caby et al., 2005; Admyre et al., 2007; Ogawa et al., 2008; Gonzales et al., 2009). The cargo of EVs contains biologically active molecules, such as nucleic acids (DNA, RNA, microRNAs and long non-coding RNAs), proteins, lipids, and nicotinamide phosphoribosyltransferase (eNAMPT) (Yoshida et al., 2019).

EVs have been shown to be involved in numerous biological functions and pathological processes (Baek et al., 2016). Meanwhile, EVs and their cargos act as non-invasive markers of 
various diseases (Li et al., 2009; Mitchell et al., 2009; Choi et al., 2011; Saman et al., 2012; Ostergaard et al., 2013; Jakobsen et al., 2015). Abnormal EV levels may be one of the causes of aging and reproductive diseases (including polycystic ovary syndrome (PCOS) and endometriosis), and are closely related to the occurrence, development, and prognosis of these diseases. Moreover, EVs can alleviate aging phenotypes, and promote cell proliferation (Liu et al., 2019). Such developments offer new therapeutic strategies for the treatment of PCOS in the future. The purpose of this review is to describe the present knowledge of the role of EVs as cell-to-cell messengers in aging and reproductive diseases.

\section{METHODS}

For this review, including three strategies: literature search, study selection, and results summary. We conducted a systematic online literature search of the PubMed and Web of Science databases and searched all published articles since the database's creation to 2019. We used the following query: ('extracellular vesicles' or 'microvesicles' or 'microparticles' or 'exosomes') and ('comparison of isolation method' or 'aging' or 'polycystic ovary syndrome' or 'endometriosis'). Both animal and human studies were considered suitable for this review. Additionally, all relevant studies were identified and included. These types of EVs do not include "apoptotic bodies" and "apoptotic vesicles". Any duplicate articles were eliminated. After screening the title and/or abstracts, if the article was found to be unrelated to the study, was excluded. A total of 9072 records were retrieved from the two databases. After removing duplicates titles and other topic articles, the full-text articles of 190 articles were reviewed and 89 were considered relevant and included in this review (Figure 1).

\section{EXTRACELLULAR VESICLES-IDENTIFICATION}

Over the past ten years, the number of published papers on EVs has increased exponentially, which is in sharp contrast with the field of circRNA. This also proves that researchers have a growing understanding of EVs, as seen in Figure 2, to the extent that the 2013 Nobel Prize in Physiology or Medicine was awarded to three scientists (James E. Rothman, Randy W. Schekman, and Thomas C. Südhof) working on the transport system of vesicles inside cells. In fact, the study of EVs dates back even further. It was in 1982 when EVs were first reported in seminal plasma (Stegmayr and Ronquist, 1982). EVs were initially considered as "cellular garbage", although they are now known as important mediators of intercellular communication, participating in and activating a variety of cell signaling pathways (Raposo and Stoorvogel, 2013).

EVs are a heterogeneous population (Bobrie et al., 2012; Raposo and Stoorvogel, 2013; Kowal et al., 2016), and can be classified into three categories according to their biogenetic pathway and physical characteristics: exosomes, microvesicles (MVs), and apoptotic bodies (Figure 3 and Table 1). Exosomes are small vesicles with lipid bilayers that contain cytoplasmic components of secretory cells which indirectly reflect the state and nature of the secretory cells and are biologically equivalent to the cytoplasm of the lipid bilayer. The external domains of transmembrane proteins are exposed in the extracellular space (Schorey et al., 2015). Exosomes are derived from intraluminal vesicles (ILVs) residing within multivesicular endosomes (MVEs) (van Niel et al., 2018). MVs can also be called microparticles (MPs), formerly known as 'dust', and are shed from the plasma membrane and subsequently released into the extracellular space (Mathieu et al., 2019). MVs may be released faster than exosomes, which is directly related to their production mechanism. Apoptotic bodies are released from dying cells (Colombo et al., 2014; Yanez-Mo et al., 2015). The production of EVs has been widely observed in bacteria, humans, and plants (Deatherage and Cookson, 2012; Schorey et al., 2015; Robinson et al., 2016), and demonstrates an evolutionarily conserved intercellular signaling mechanism. Exosomes are small vesicles of $40-150 \mathrm{~nm}$ in diameter (Jeppesen et al., 2019), although can potentially reach as large as $200 \mathrm{~nm}$ (Colombo et al., 2013), and therefore overlap the range of virus sizes (Gyorgy et al., 2011). MVs vary in size from 100 to $1,000 \mathrm{~nm}$ in diameter (Marques et al., 2013), up to 10 $\mu \mathrm{m}$, and overlap the range of bacteria sizes (Akers et al., 2013). Apoptotic bodies are the largest vesicles $(>1,000 \mathrm{~nm})$ of the three classes and overlap the rang of platelet diameter (Hristov et al., 2004; Atkin-Smith et al., 2015). In fact, the diameter of vesicles does not sufficiently differentiate exosomes and MVs because in some instances their diameters may overlap with each other. Typical biomarkers for exosomes include transmembrane tetrad proteins (e.g., CD9, CD63, and CD81), Alix, TSG101, Flotillin-1, HSC70, and syntenin-1 (Mathivanan et al., 2010; Colombo et al., 2014). Discriminatory markers of MVs include annexin A1, ARF6, KIF, RACGAP, exportin-2, and chromosome segregation 1-like protein (Muralidharan-Chari et al., 2009; Xu et al., 2016; Tricarico et al., 2017; Jeppesen et al., 2019). Phosphatidylserine (PS), thrombospondin, C3b complement protein, calreticulin, and VDAC1 have been proven to be useful markers for apoptotic bodies (Takizawa et al., 1996; Fadok et al., 2001; Friedl et al., 2002; Jeppesen et al., 2014; Van Deun et al., 2014).

\section{EXTRACELLULAR VESICLES ISOLATION METHODS}

Many techniques have been established to isolate different EVs. Ultracentrifugation (UC) is one of the most commonly used methods for exosomal isolation. Extension of UC time increases the degree of pollution of non-vesicular particles (Cvjetkovic et al., 2014). Non-vesicular components are likely to be contaminating and mainly include high molecular weight proteins and protein aggregates that co-precipitate with exosomes during the UC process (Tauro et al., 2012). Moreover, UC shows the lowest recovery, but the highest protein purity of all exosomal isolation methods (Tang et al., 2017). Therefore, the UC method is the ideal option for proteomic analysis of exosomes (Alvarez et al., 2012; Rekker et al., 2014). In recent years, a series of commercial kits have been developed for the 


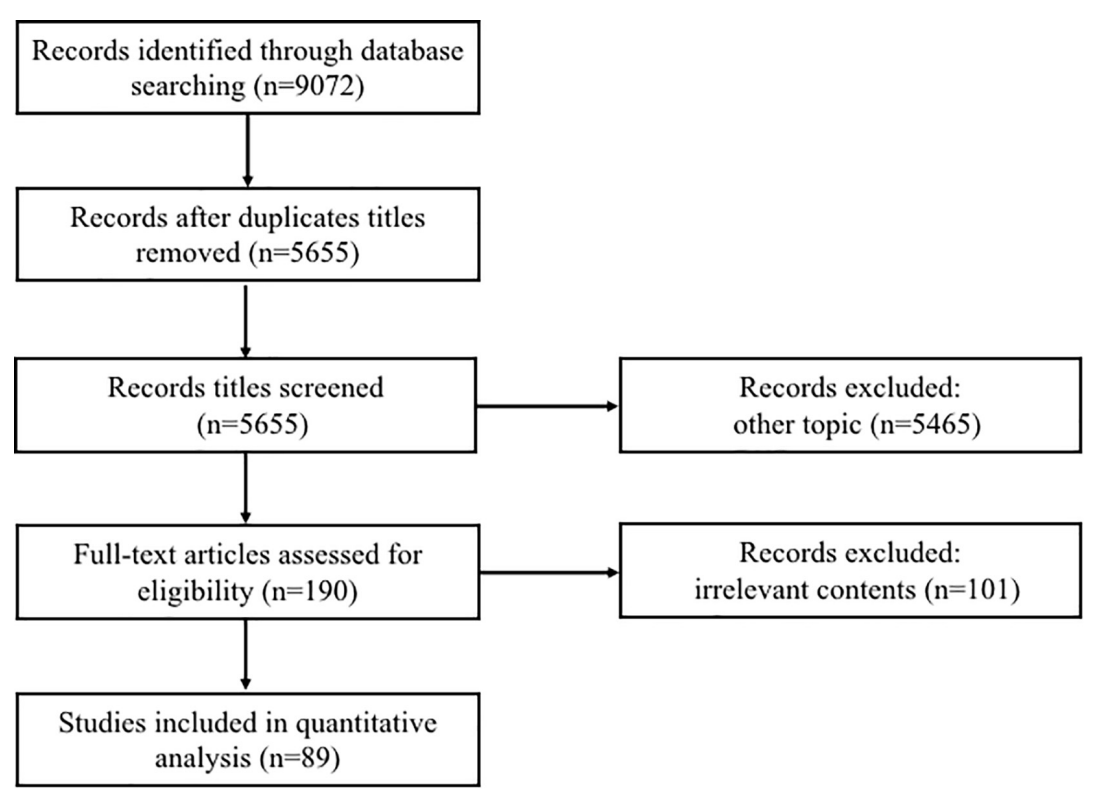

FIGURE 1 | Schematic of study selection.

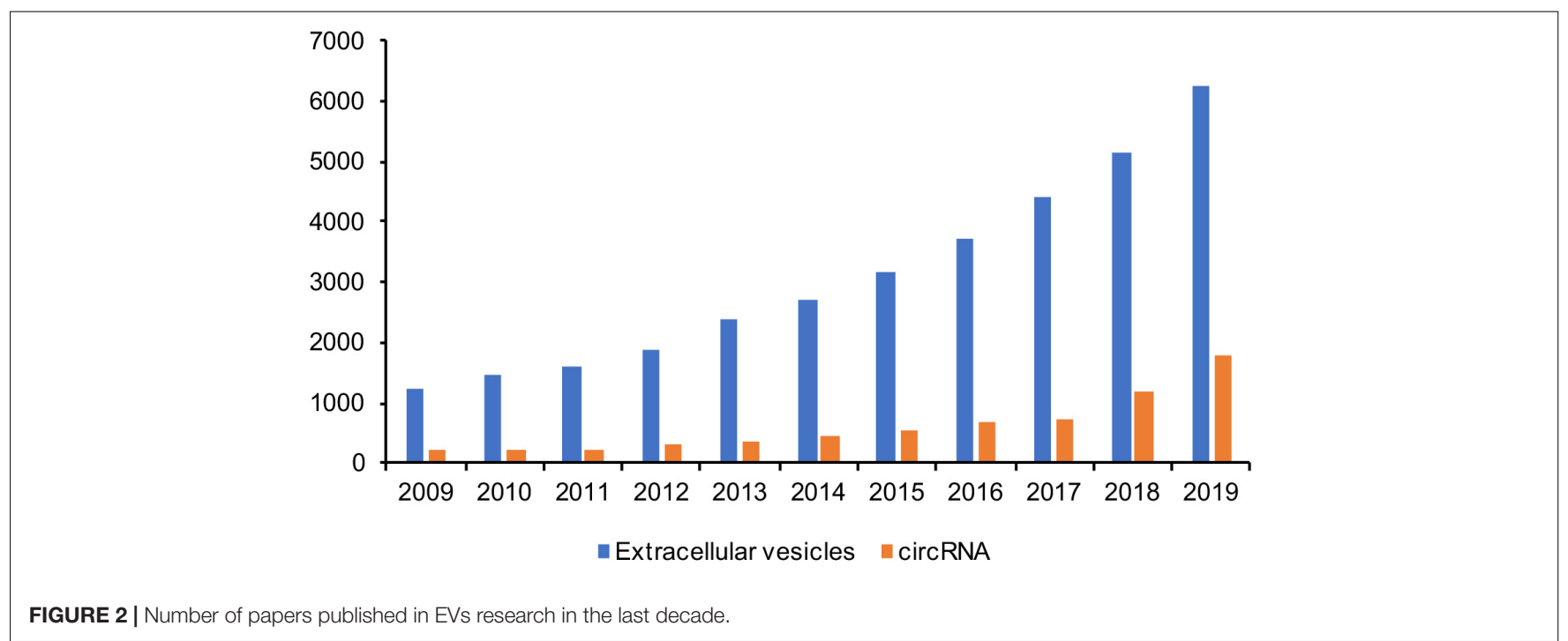

isolation and extraction of exosomes (Hartman et al., 2011; da Silveira et al., 2012; Sohel et al., 2013). Compared to the UC method, commercial kits have simple methods (Helwa et al., 2017), often produce a significantly higher yield of exosomes (Helwa et al., 2017), and show a higher extraction efficiency (Tang et al., 2017). However, albumin impurities in the final extract are common. Notably, commercial kits produced the highest numbers of exosome miRNA and mRNA. Therefore, the use of commercial kits is an ideal method for subsequent RNA profiling analysis (Alvarez et al., 2012). Lastly, immunoaffinity capture is another method for separating and purifying exosomes. This method allows for the purification of high levels of exosomes and the exosome-associated proteins (Greening et al., 2015), and this is suitable for protein analysis of exosomes.
The selection of exosome isolation methods will have a substantial impact on the following RNA and protein analysis. Therefore, an appropriate exosome isolation method is essential to reveal exosomal-specific contents, and biological functions.

\section{EXTRACELLULAR VESICLES AND AGING}

Aging can be defined by a decline in multiple biological functions. There are many aging-associated disorders and chronic diseases, for example, sarcopenia (Landi et al., 2018), cancers, and cardiovascular diseases. This time-dependent process is characterized by the accumulation of cellular damage, 


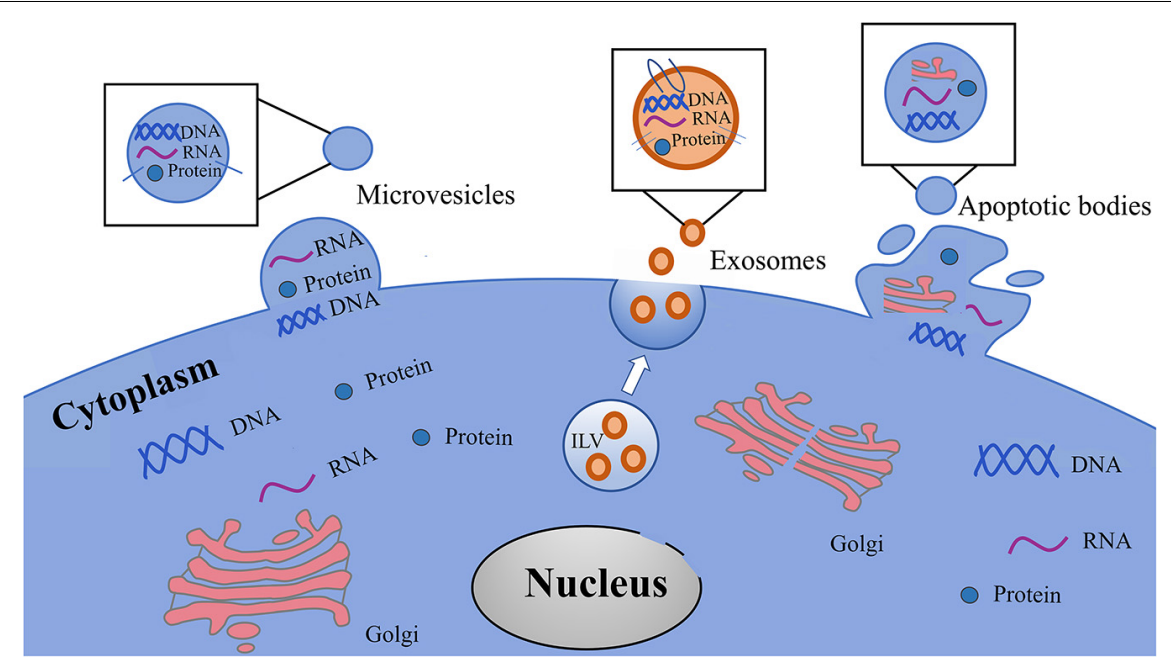

FIGURE 3 | Types of EVs in the cells culture media and body fluids. EVs are classified in three heterogeneous population, including exosomes, microvesicles and apoptotic bodies. Exosomes are originated from intraluminal vesicles (ILVs) reside within multivesicular endosomes (MVEs) that are the precursor of exosomes. Microvesicles shedding from the plasma membrane and subsequently released into the extracellular space. Apoptotic bodies are released from dying cells.

TABLE 1 | Summary of key characteristics of microvesicles, exosomes and apoptotic bodies.

\begin{tabular}{|c|c|c|c|c|}
\hline & Microvesicles & Exosomes & Apoptotic bodies & References \\
\hline Size (nm) & $\begin{array}{l}100 \text { to } 1,000 / 10,000 \\
\text { overlaps with bacteria size }\end{array}$ & $\begin{array}{l}40 \text { to } 150 / 200 \\
\text { overlap with virus size }\end{array}$ & $\begin{array}{l}>1,000 \\
\text { overlaps with platelet } \\
\text { diameter }\end{array}$ & $\begin{array}{l}\text { Hristov et al., 2004; Gyorgy et al., 2011; Akers et al., 2013; } \\
\text { Colombo et al., 2013; Marques et al., 2013; Atkin-Smith } \\
\text { et al., 2015; Jeppesen et al., } 2019\end{array}$ \\
\hline $\begin{array}{l}\text { Isolation } \\
\text { procedure }\end{array}$ & $\begin{array}{l}\text { Sequential centrifugation } \\
(300 \mathrm{~g} / 2,000 \mathrm{~g} / 10,000 \mathrm{~g})\end{array}$ & $\begin{array}{l}\text { Ultracentrifugation (UC), } \\
\text { commercial kits, immunoaffinity, } \\
\text { size exclusion, polymeric } \\
\text { precipitation, microfluidics, }\end{array}$ & $\begin{array}{l}\text { Centrifugation }(300 \mathrm{~g}) \text {, } \\
\text { sequential filtering }(5 \\
\text { and } 1 \mu \mathrm{m} \text { filters }) \text { and } \\
\text { centrifugation( } 2,000 \mathrm{~g})\end{array}$ & $\begin{array}{l}\text { Chen et al., 2010, Hartman et al., 2011, Taylor et al., 2011; } \\
\text { da Silveira et al., 2012; Sohel et al., 2013; Witwer et al., } \\
\text { 2013; Boing et al., 2014; Van Deun et al., 2014; Greening } \\
\text { et al., 2015; Xu et al., } 2015\end{array}$ \\
\hline $\begin{array}{l}\text { Selected protein } \\
\text { markers }\end{array}$ & $\begin{array}{l}\text { Annexin A1, ARF6, KIF, } \\
\text { RACGAP, exportin-2 and } \\
\text { chromosome segregation } \\
\text { 1-like protein }\end{array}$ & $\begin{array}{l}\text { Transmembrane tetrad proteins } \\
\text { (including CD9, CD63, and CD81), } \\
\text { Alix, TSG101, Flotillin-1, HSC70 } \\
\text { and syntenin-1 }\end{array}$ & $\begin{array}{l}\text { VDAC1, PS, } \\
\text { thrombospondin, C3b, } \\
\text { calreticulin. }\end{array}$ & $\begin{array}{l}\text { Takizawa et al., 1996; Fadok et al., 2001; Friedl et al., 2002; } \\
\text { Muralidharan-Chari et al., 2009; Mathivanan et al., 2010; } \\
\text { Colombo et al., 2014; Jeppesen et al., 2014, 2019; Van } \\
\text { Deun et al., 2014; Xu et al., 2016; Tricarico et al., } 2017\end{array}$ \\
\hline Biogenesis & $\begin{array}{l}\text { Shedding from the plasma } \\
\text { membrane and } \\
\text { subsequently released into } \\
\text { the extracellular space }\end{array}$ & $\begin{array}{l}\text { Originate from intraluminal vesicles } \\
\text { (ILVs) reside within multivesicular } \\
\text { endosomes (MVEs) and are the } \\
\text { precursor of exosomes }\end{array}$ & $\begin{array}{l}\text { Released from dying } \\
\text { cells }\end{array}$ & $\begin{array}{l}\text { Colombo et al., 2014; Yanez-Mo et al., 2015; van Niel et al., } \\
\text { 2018; Mathieu et al., } 2019\end{array}$ \\
\hline
\end{tabular}

widely recognized as a common cause of aging (Kirkwood, 2005; Gems and Partridge, 2013). A typical hallmark of senescent cells is the stability of permanent cell cycle arrest. Generally, the DNA synthesizing ability of senescent cells are typical of the G1 phase (Di Leonardo et al., 1994; Herbig et al., 2004). Aging has nine hallmarks: genomic instability, telomere shortening, epigenetic alterations, loss of proteostasis, deregulated nutrient sensing, mitochondrial dysfunction, senescence, stem cell exhaustion, and alteration in intercellular communication (Shiels et al., 2017). Cells in senescence exhibit a senescence-associated secretory phenotype (SASP), triggering the loss of DNA replication capacity (Campisi and d'Adda di Fagagna, 2007). Previous studies about aging have focused on traditional fields such as genetic alterations and epigenetics. With the development of EVs separation technology and the deepening of theoretical research, we have a new understanding of the mechanism of aging. Recently, EVs and their contents have received extensive attention in the research of aging mechanism.
EVs play a fundamental role in aging (Pusic and Kraig, 2014; Alique et al., 2017). Takasugi et al. (2017) demonstrated that EVs secreted by DNA-damaging agent doxorubicin induced senescent RPE-1 cells are important mediators of the pro-tumorigenic function of senescent cells. EVs-associated EphA2 secreted from senescent cells binds to ephrin-A1, which is highly expressed in several types of cancer cells and promotes cell proliferation through EphA2/ephrin-A1 reverse signaling. However, recent finding indicated that induced pluripotent stem cells (iPSCs) produce a large number of EVs, which could alleviate the aging-associated phenotypes of senescent mesenchymal stem cells (MSCs), promote cell proliferation, and mitigate progerininduced senescence in premature aging cell models (Liu et al., 2019). Research into stem cells and their secreted EVs could help address the negative effects of senescent cells. This research would differ in that it requires the use of different cell sources of EVs.

At present, there are many controversies about whether EVs secretion in senescent cells is increased or decreased. In 
2008, Lehmann et al. (2008) first certified that the release of EVs secretion increased during proliferative senescence in normal human diploid fibroblasts. This increase is regulated by p53 and TSAP6 (the target gene of p53). However, the exact mechanism of this regulation remains unclear. However, Eitan et al. (2017) provided an analysis of EVs in peripheral blood circulation through an epidemiologic and longitudinal study, and showed that the concentration of EVs significantly decreased with increasing age. This contrasting age-related decrease in EVs may be partly attributed to the fact that EVs from senescent individuals are easier to internalize than those from more young and healthy individuals (Eitan et al., 2017). The protein levels in EVs may be account for the age-related concentration changes and internalization activation. Recent studies revealed that the apoptosis markers such as p53, cleaved PARP, and cleaved Caspase- 3 are significantly decreased, while proteins including CD151 and tetraspanin are markedly increased with cell senescence (Eitan et al., 2017). Therefore, the change of EVs levels in senescent cells needs further study.

The contents of EVs are also closely related to senescence, such as miRNA, inflammatory cargos, nicotinamide phosphoribosyltransferase, DNA and C24:1 ceramide.

\section{miRNA}

Recently, a new mechanism of intercellular communication mediated by exosome-associated miRNAs has attracted widespread attention (Valadi et al., 2007). miRNAs are short non-coding RNA (ncRNA) molecules that can act as gene regulators by inhibiting translation or binding to the three primes' untranslated region (3'-UTR) of target messenger RNA (mRNA) to induce degradation of the target mRNA transcripts (Gasparello et al., 2019). miRNAs are therefore believed to be important in a range of physiological processes and the regulation of the development of many diseases. Moreover, Wei et al. (2017) recently analyzed extracellular RNA (exRNA) of EVs secreted by glioblastoma cells in vitro and found that ncRNA composed the majority of exRNA, instead of mRNA. This indicates that miRNAs play a significant and ever-growing role in the implementation of EVs function.

Studies have shown that exosome miRNA can be transported to surrounding tissues or cells and exert either a positive or negative impact, as summarized in Table 2. Several exosomeassociated miRNAs are important regulators of senescence and cellular senescence. Exosomal miRNAs from senescent cells can be transported to surrounding cells and lead to aging (Smith-Vikos and Slack, 2012; Urbanelli et al., 2016). For example, Davis et al. (2017) treated bone marrow mesenchymal stem cells (BMSCs) of young mice with EVs derived from the bone marrow of aging mice and found that osteogenic differentiation was inhibited and BMSCs senescence was induced. This phenomenon can be mimicked by the transfection of miR-183-5p into BMSCs. Aging of the brain is associated with the loss of myelin, which has been shown to directly cause cognitive decline (Pusic and Kraig, 2014). In this study, serumderived exosome miRNA in young Wistar rats promoted the
TABLE 2 | EVs cargos involved in aging.

\begin{tabular}{|c|c|c|}
\hline Cargos & Functions & References \\
\hline \multirow[t]{6}{*}{ miRNA } & $\begin{array}{l}\text { Inhibit BMSCs osteogenic } \\
\text { differentiation and induced } \\
\text { senescence }\end{array}$ & Davis et al., 2017 \\
\hline & $\begin{array}{l}\text { Promote the oligodendrocyte } \\
\text { precursor cells differentiation and } \\
\text { improve the ability of } \\
\text { remyelination }\end{array}$ & $\begin{array}{l}\text { Pusic and Kraig, } \\
2014\end{array}$ \\
\hline & $\begin{array}{l}\text { Promote osteoclast formation } \\
\text { and bone reabsorption, leading to } \\
\text { the occurrence of osteoporosis }\end{array}$ & Xu et al., 2018 \\
\hline & $\begin{array}{l}\text { Stimulate receptor cell migration } \\
\text { and angiogenesis, preventing } \\
\text { senescence }\end{array}$ & $\begin{array}{l}\text { van Balkom et al., } \\
2013\end{array}$ \\
\hline & $\begin{array}{l}\text { Sensitivity and specificity to } \\
\text { predict } A D\end{array}$ & Lugli et al., 2015 \\
\hline & $\begin{array}{l}\text { A novel candidate aging } \\
\text { biomarker }\end{array}$ & $\begin{array}{l}\text { Machida et al., } \\
\text { 2015; Bertoldi } \\
\text { et al., } 2018\end{array}$ \\
\hline Inflammatory cargos & $\begin{array}{l}\text { Participate in the spread of } \\
\text { inflammatory diseases }\end{array}$ & $\begin{array}{l}\text { Boilard et al., 2010; } \\
\text { Gomes de Andrade } \\
\text { et al., } 2018\end{array}$ \\
\hline $\begin{array}{l}\text { Nicotinamide } \\
\text { phosphoribosyltransferase } \\
\text { (eNAMPT) }\end{array}$ & $\begin{array}{l}\text { Promote the biosynthesis of } \\
\text { systemic } \mathrm{NAD}^{+} \text {and offsets the } \\
\text { occurrence of aging }\end{array}$ & Yoshida et al., 2019 \\
\hline DNA & Maintain cellular homeostasis & $\begin{array}{l}\text { Ostrowski et al., } \\
\text { 2010; Baietti et al., } \\
\text { 2012; Takahashi } \\
\text { et al., } 2017\end{array}$ \\
\hline \multirow[t]{2}{*}{ C24:1 ceramide } & $\begin{array}{l}\text { A key factor in cell death and } \\
\text { senescence }\end{array}$ & Venable et al., 1995 \\
\hline & $\begin{array}{l}\text { Induce senescence of bone } \\
\text { marrow mesenchymal stem cells }\end{array}$ & $\begin{array}{l}\text { Khayrullin et al., } \\
2019\end{array}$ \\
\hline
\end{tabular}

EVs: Extracellular vesicles. BMSCs: Bone marrow mesenchymal stem cells.

differentiation of primary oligodendrocyte precursor cells (OPC) and improved the ability of remyelination in older Wistar rats. In the microenvironment of bone marrow, age-related miRNA changes can inhibit bone formation and promote bone resorption, leading to the osteoporosis. Exosomes derived from older rats BMSCs promoted the occurrence of osteoporosis and had higher levels of miR-31a-5p, compared to that of younger rats. Therefore, exosome miRNA is considered to be as an important mediator in the age-related bone marrow microenvironment (Xu et al., 2018).

However, exosomes can also suppress cellular senescence in certain contexts. Exosomes have been considered to be messengers of intercellular communication during angiogenesis. Recent studies have revealed that exosomes containing miR214, produced by the human microvascular endothelial cell line (HMEC-1), can stimulate receptor cell migration and angiogenesis, thereby preventing the development of senescence. In contrast, the depletion of exosome miR-214 in endothelial cells failed to stimulate these processes and prevent cellular senescence (van Balkom et al., 2013). The study of miRNA in young and senescent cell EVs is helpful to reveal the new mechanisms of senescence. 
Exosome miRNAs are also considered to be potential attractive biomarkers of aging (Smith et al., 2015). In a study investigating Alzheimer's disease (AD), Lugli et al. (2015) strongly suggested that plasma exosome miR-1306-5p, which targeted ADAM10, had the best sensitivity and specificity to predict $\mathrm{AD}$, of all indicators examined. In salivary exosomes, miR-24-3p has been identified as a novel candidate biomarker for aging (Machida et al., 2015). The miR-183 cluster of exosomes, comprising miR-96, miR-182, and miR-183, increased during the aging process (Bertoldi et al., 2018). This suggests that the miR-183 clusters have the potential serve as biomarkers of aging.

\section{INFLAMMATORY CARGOS}

Inflammation has long been considered a defensive response to microbial agents. It is now clear that an inflammatory response can occur in the absence of infection, in a condition known as "aseptic inflammation" (Chen and Nunez, 2010). Aseptic inflammation is referred to as a chronic systemic inflammatory state during aging (Franceschi et al., 2000), in which EVs are involved (Table 2). EVs can trigger aseptic inflammatory responses by carrying pathogen autoantigens or damage-associated molecular patterns, and are involved in the transmission of inflammatory diseases through EV-associated cytokines, miRNAs, and lipid mediators (Buzas et al., 2014). Boilard et al. (2010) suggested that MPs originating from platelet are able to promote inflammatory reactions and stimulate cytokine responses in synovial fibroblasts via interleukin-1 (IL-1) signaling. Gomes de Andrade et al. (2018) revealed that aging could cause changes in the profiles of circulating exosomes. An age-related increase in CD63 levels was observed in exosomes from cerebrospinal fluid (CSF), and a significant decrease in IL$1 \beta$ levels was observed in exosomes from the plasma of the older group of male Wistar rats (Gomes de Andrade et al., 2018). These results suggest that changes in IL- $1 \beta$ levels of the exosomes are significantly correlated with age-related inflammatory responses.

\section{NICOTINAMIDE PHOSPHORIBOSYLTRANSFERASE}

Nicotinamide adenine dinucleotide (NAD) is the basic chemical involved in energy metabolism in all living organisms. The expression of $\mathrm{NAD}^{+}$, the oxidized form of $\mathrm{NAD}$, in worms, various rodent tissues (fat, skeletal muscle, liver, pancreas, kidney, brain and heart), skin, and neurosensory retina is decreased with age (Braidy et al., 2011; Gomes et al., 2013; Mouchiroud et al., 2013; Khan et al., 2014; Canto et al., 2015; Verdin, 2015; Lin et al., 2018; Rajman et al., 2018; Yoshino et al., 2018). eNAMPT is an essential $\mathrm{NAD}^{+}$biosynthetic enzyme in mammals. In recent years, $\mathrm{NAD}^{+}$metabolism has become a hot topic in the field of aging (Canto et al., 2015; Rajman et al., 2018). Through the enrichment of several exosome markers, such as Flotillin-1, TSG101, CD9, CD63, and CD81, as well as the use of electron microscopy, Yoshida et al. (2019) demonstrated that both mouse and human plasma exosomes contained eNAMPT, which was internalized into target cells to directly enhance cellular $\mathrm{NAD}^{+}$biosynthesis. Moreover, in aging mouse plasma, exosomecontaining eNAMPT content can be changed. This is a novel inter-organizational communication mechanism that maintains $\mathrm{NAD}^{+}$levels through exosome-mediated eNAMPT transport. eNAMPT promotes the biosynthesis of systemic $\mathrm{NAD}^{+}$, offsets the occurrence of aging, and can be used as a new potential anti-aging intervention pathway (Table 2).

\section{DNA}

EVs also contain chromosomal DNA fragments. It has been reported that no matter the cause of cellular senescence, the secretion of DNA-containing exosomes increases with cell senescence (Takahashi et al., 2017). In senescent human cells, the inhibition of exosome-associated DNA secretion by knocking down Alix or Rab27, which are important molecules for the biogenesis (Baietti et al., 2012) and secretion (Ostrowski et al., 2010) of the exosomes, can provoke reactive oxygen species (ROS)-dependent DNA damage due to the accumulation of DNA in the cytoplasm and senescent cell cycle arrest or cell apoptosis. Even in non-senescent cells, the accumulation of cytoplasmic DNA can induce apoptosis. Cytoplasmic DNA has been reported as a danger signal that activates the innate immune response, including the interferon (IFN) pathway (Abe et al., 2013; Hartlova et al., 2015) and cGAS-STING-dependent signaling (Takahashi et al., 2017). Meanwhile, exosomes are actively secreted from cells in order to the remove infected adenoviral DNA (Takahashi et al., 2017). Exosomes, are therefore believed to play a critical role in senescence-associated secretory phenotypes. These results suggest that exosome secretion can maintain cellular homeostasis by removing harmful cytoplasmic DNA in senescent and nonsenescent cells (Table 2). These findings will provide new insights into the control of cell homeostasis as well as new facets to investigate the involvement of EVs.

\section{C24:1 CERAMIDE}

Ceramide is a sphingolipid produced by the hydrolysis of sphingomyelin, catalyzed by sphingomyelinase (Wang et al., 2012), and has various of forms, such as short-, medium-, long-, and very long-chain. EVs are highly abundant in sphingolipid ceramide (Wang et al., 2012). Lipidomic analyses of serum exosomes indicated that serum exosomes from older women were highly enriched in C24:1 ceramide (Khayrullin et al., 2019). Exosome-associated ceramide has emerged as a key factor in cell death and senescence in a variety of cell types (Venable et al., 1995). Recent studies by Law et al. (2018) revealed that very long-chain ceramides with lipotoxicity can cause mitochondrial dysfunction, oxidative stress, and cell death in cardiomyocytes. In vitro experiments have shown that exosomes containing C24: 1 ceramide in serum could induce the senescence of BMSCs (Khayrullin et al., 2019). These results confirm that exosomes containing C24: 1 ceramide may directly lead to the involuntary senescence and apoptosis of cells (Table 2). 
These animal and human studies provide strong evidence for the relationship between EVs, cargos, and aging. In the future studies, the relationship between other contents of EVs and senescence should be further explored to reveal the potentially unexpected role of EVs.

\section{EXTRACELLULAR VESICLES AND REPRODUCTIVE DISEASES}

It is widely accepted that normal reproductive processes, including ovulation, menstruation, implantation, and parturition, show signs of inflammation (Goswami et al., 2008). The female reproductive tract needs to solve these problems quickly to restore normal reproductive function. The dysregulation of inflammatory factors play a pivotal role in reproductive diseases (Gupta et al., 2008). As we know, EVs are involved in inflammatory state. In this review, we emphasize the involvement of EVs in PCOS and endometriosis. In view of the functions and characteristics of EVs, we focus on assessing the pathogenic role as well as diagnostic and therapeutic value of EVs in PCOS and endometriosis (Table 3).

\section{EXTRACELLULAR VESICLES AND POLYCYSTIC OVARY SYNDROME}

PCOS is one of the most prevalent endocrine diseases in women of reproductive age (Bozdag et al., 2016). Importantly, women with PCOS have an imbalance between procoagulant and anticoagulant factors with increased levels of proinflammatory cytokines (Repaci et al., 2011; Palomba et al., 2015; Nehir Aytan et al., 2016), which increase the risk of cardiovascular disease. Mesri and Altieri (1998) first described the role of circulating EVs in the spread of endothelial proinflammatory cascades in 1998. They demonstrated that EVs released from polymorphonuclear leukocytes by healthy volunteers could induce endothelial cells to produce cytokines and chemokines in vitro. In follicular fluids of PCOS women, Li et al. (2019) used a tandem mass tag quantitative proteomic approach and found that follicular fluid exosomes of both normal and PCOS samples contained S100 calcium-binding protein A9 (S100A9). S100-A9 expression was greater in the follicular fluid exosomes of PCOS women and enhanced inflammation and disrupted steroidogenesis by activating the nuclear factor kappa $\mathrm{B}(\mathrm{NF}-\kappa \mathrm{B})$ signaling pathway. This activation was performed in a S100-A9 dose-dependent manner. In the follicular fluids of PCOS patients, EVs miR-132 and miR-320 are expressed at significantly lower levels than in healthy individuals (Sang et al., 2013). Moreover, these two miRNAs are also related to the production of steroidogenesis. However, the women with PCOS, miR-323-3p derived from mesenchymal stem cell exosomes alleviates PCOS by targeting PDCD4 to promote proliferation and inhibit apoptosis of cumulus cells (Zhao et al., 2019). This provides a novel therapeutic strategy for the treatment of PCOS.

MPs are also a type of EVs and play a fundamental role in the communication between source and target cells. Serum MPs' content can increase in variety of conditions, including PCOS (Willis et al., 2014; Carvalho et al., 2017b), prothrombotic states (Mooberry et al., 2016), and type 2 diabetes mellitus (Koga et al., 2005). Younger women with PCOS have increased concentrations of circulating annexin V-positive platelet MPs in plasma, compared with older women with PCOS (Willis et al., 2014). Surprisingly, in overweight women with the PCOS, plasma MPs are also higher than those in BMI-matched controls (Koiou et al., 2013). It was subsequently confirmed that elevated levels of EVs in women with PCOS are directly related to follicular counts and insulin resistance markers in the ovary (Simon et al., 2018). Interestingly, recent studies have revealed that metformin could reduce total MPs and tissue factor MPs (TFMPs) in women with PCOS (Carvalho et al., 2017a). TFMPs participate in thrombus formation and clot propagation (Nomura and Shimizu, 2015). Moreover, following

TABLE 3 | Pathogenic role and main functions of EVs in polycystic ovary syndrome and endometriosis.

\begin{tabular}{|c|c|c|c|}
\hline Disease & Pathogenic role of EVs & Potential functions & References \\
\hline \multirow[t]{3}{*}{ PCOS } & $\begin{array}{l}\text { Enhance inflammation and disrupt steroidogenesis by activating } \\
\text { the NF-кB signaling pathway }\end{array}$ & & Li et al., 2019 \\
\hline & $\begin{array}{l}\text { Alleviate PCOS by targeting PDCD4 to promote proliferation and } \\
\text { inhibit apoptosis of cumulus cells }\end{array}$ & New therapeutic strategy & Zhao et al., 2019 \\
\hline & & Biomarkers for predicting PCOS & Carvalho et al., 2017b \\
\hline \multirow[t]{7}{*}{ Endometriosis } & Reflect the state of the inflammation and/or procoagulant system & & Munros et al., 2017 \\
\hline & Increase total weight and impair macrophages' phagocytic ability & & Sun et al., 2019 \\
\hline & $\begin{array}{l}\text { Contribute to endometriosis by affecting inflammation, angiogenesis, } \\
\text { and proliferation in the microenvironment of endometriotic lesions }\end{array}$ & & Khalaj et al., 2019 \\
\hline & & Prediction of successful embryo implantation & Parks et al., 2018 \\
\hline & $\begin{array}{l}\text { Decrease of endometriosis fibrosis by reducing Collagen } \alpha \mathrm{l} \text { and } \\
\text { CTGF mRNA expression }\end{array}$ & & Wu et al., 2018 \\
\hline & Promote the occurrence of endometriosis and regulate angiogenesis & & Harp et al., 2016, Qiu et al., 2019 \\
\hline & & $\begin{array}{l}\text { A non-invasive detection marker in the } \\
\text { diagnosis of endometriosis }\end{array}$ & Muth et al., 2015 \\
\hline
\end{tabular}

EVs: Extracellular vesicles. PCOS: Polycystic ovary syndrome. NF-кB: nuclear factor kappa B. 
weight loss in a patient with PCOS, the number of MPs was significantly decreased. The relationship between MPs and the other symptoms of PCOS have not yet been established (Teede et al., 2010).

MPs may serve as useful biomarkers for predicting many diseases, including PCOS and cardiovascular disease (Carvalho et al., 2017b). The ratio of ornithine to arginine in plasma derived from PCOS patients is significantly increased (Kyselova et al., 2019). Furthermore, platelet-derived MPs are the main sources of plasma arginase (Kyselova et al., 2019). Arginase and the ratio of ornithine to arginine have also been reported to represent early biomarkers of potential cardiovascular disease in PCOS patients (Kyselova et al., 2019). Therefore, MPs can be used as potential biomarkers for disease assessment. The role of EVs in PCOS requires further study.

\section{EXTRACELLULAR VESICLES AND ENDOMETRIOSIS}

Endometriosis is a hormone-dependent, chronic, painful, and benign gynecological disorder. Although the pathogenesis of endometriosis is still unknown, Sampson's can explain the etiology of this disease through the theory of retrograde menstruation. This theory suggests that menstrual discharge returns to the peritoneal cavity through uterine contraction, adheres to the peritoneal tissue, and develops into ectopic lesions. However, of all patients with retrograde menstruation, only 5\%-10\% develop endometriosis (Cramer and Missmer, 2002; Giudice, 2010). Therefore, endometriosis is considered to be a dysfunctional immune response (Paul Dmowski and Braun, 2004) which promotes inflammatory responses and angiogenesis. Lately, the immune mechanism of endometriosis has received increasing attention (Ballester et al., 2011), notably due to the prevalence of EVs-related endometriosis research. Khalaj et al. (2019) suggested that in endometriosis patients, EVs could contribute to endometriosis by affecting inflammation, angiogenesis, and proliferation in the microenvironment of endometriotic lesions. Sun et al. (2019) reported that endometriosis, an inflammatory disease, possibly involves peritoneal macrophages. EVs derived from eutopic stromal cells of endometriosis could increase the total weight of mice and impair phagocytic ability of macrophages. These stromal cell-derived EVs contribute to the development of lesions. Previous studies by Munros et al. (2017) showed that in deep-infiltrating endometriosis patients, increased levels of circulating total cell-derived MPs may be reflect the state of the inflammation and procoagulant system. The increase in EVs level induces the disorder of immune function, and thus promotes the occurrence of endometriosis. Therefore, EVs have been shown to have the potential to promote endometriosis.

On the other hand, in terms of pathology, the main feature of endometriosis is ectopic tissue fibrosis, which is characterized by excessive deposition of endometriotic tissue on the extracellular matrix (Matsuzaki and Darcha, 2014; Malutan et al., 2015) and may cause scar formation or alter tissue function (Matsuzaki et al., 2010). Wu et al. (2018) reported that the increase in exosome miR-214 from endometrial stromal cells could result in the decrease of endometriosis fibrosis by reducing collagen $\alpha \mathrm{I}$ and CTGF mRNA expression. Subsequently, Harp et al. (2016) proposed that exosomes released by endometriotic stromal cells could deliver specific miRNA molecules in an autocrine and paracrine manner to promote the occurrence of endometriosis and regulate angiogenesis. More recently, a study by Qiu et al. (2019) revealed that the serum exosome long non-coding RNA (lncRNA) hypoxia-inducible factor from patients with endometriosis could also promote angiogenesis. These results indicate that exosomes can promote the occurrence of endometriosis and may become an important pathogenesis for endometriosis.

Currently, the combination of laparoscopic evaluation and biopsy is the gold standard for the diagnosis of endometriosis (Gordts et al., 2015). However, both detection methods are invasive. EVs, as non-invasive detection markers, have shown to be value prospective for the diagnosis of endometriosis. Muth et al. (2015) showed that EVs from cervicovaginal lavage and vaginal swabs could be used as a novel and relatively noninvasive method to diagnose primate endometrial disease and other reproductive tract diseases.

\section{EXTRACELLULAR VESICLES APPLICATION IN CLINICAL AND BASIC RESEARCH}

The clinical application of EVs is based on four aspects (Table 4). First, treatment tools. EVs can increase the secretion of proinflammatory cytokines (Prado et al., 2008), and thus reducing the production or absorption of EVs may be a new strategy for the treatment of diseases. Secondly, EVs are

TABLE 4 | EVs application in clinical and basic research.

\begin{tabular}{ll}
\hline EVs application & References \\
\hline Clinical & \\
Treat tools & Prado et al., 2008 \\
Promising biomarkers for & Lugli et al., 2015; Machida et al., 2015; Muth \\
diagnostic diseases & et al., 2015; Carvalho et al., 2017b; Bertoldi \\
& et al., 2018; Kyselova et al., 2019 \\
Drug delivery tools & Yoshida et al., 2019 \\
Vaccines & Raposo et al., 1996; Zitvogel et al., 1998; \\
& Chaput and Thery, 2011
\end{tabular}

Basic research

Function: Influence inflammation, Mesri and Altieri, 1998; Boilard et al., 2010; angiogenesis, disrupting Harp et al., 2016; Munros et al., 2017; Gomes steroidogenesis and impairing de Andrade et al., 2018; Khalaj et al., 2019; Li macrophages' phagocytic ability. et al., 2019; Qiu et al., 2019; Sun et al., 2019 Alleviation diseases development.

Mechanism: the NF-кB signaling Li et al., 2019; Zhang et al., 2019 pathway

Wu et al., 2018; Liu et al., 2019; Mobarak et al., 2019; Yoshida et al., 2019; Zhao et al., 2019

EVs: Extracellular vesicles. NF-кB: nuclear factor kappa B. 
promising biomarkers for diagnostic diseases (Lugli et al., 2015; Machida et al., 2015; Muth et al., 2015; Carvalho et al., 2017b; Bertoldi et al., 2018; Kyselova et al., 2019). EVs from bodily fluid have gained significant interest as a potential diagnostic biomarker for various diseases. Thirdly, EVs can be utilized as drug delivery tools. EVs can transport cargos to adjacent cells and be internalized into cells (Yoshida et al., 2019). Lastly, EVs may be applied to vaccinations. EVs have the potential to improve immune function (Raposo et al., 1996; Zitvogel et al., 1998; Chaput and Thery, 2011). The properties of EVs regulate the immune system, and thus give them the possibility to be involved in vaccinations.

In basic research, on the one hand, EVs contribute to disease pathophysiology. EVs and cargos include protein, miRNAs and lncRNAs that promote the development of the disease by influencing inflammation, angiogenesis, steroidogenesis and macrophage phagocytic ability (Mesri and Altieri, 1998; Boilard et al., 2010; Harp et al., 2016; Munros et al., 2017; Gomes de Andrade et al., 2018; Khalaj et al., 2019; Li et al., 2019; Qiu et al., 2019; Sun et al., 2019). This effect may be mediated by the NF- $\kappa B$ signaling pathway (Li et al., 2019; Zhang et al., 2019). On the other hand, EVs can also alleviate disease development (Wu et al., 2018; Liu et al., 2019; Mobarak et al., 2019; Yoshida et al., 2019; Zhao et al., 2019). It may also be a new pathway to treatment diseases.

\section{CONCLUSION}

In the recent decades, research on aging and reproductive diseases is mainly based on traditional fields such as genetic alterations and epigenetics. For this reason, many studies

\section{REFERENCES}

Abe, T., Harashima, A., Xia, T., Konno, H., Konno, K., Morales, A., et al. (2013). STING recognition of cytoplasmic DNA instigates cellular defense. Mol. Cell 50, 5-15. doi: 10.1016/j.molcel.2013.01.039

Admyre, C., Johansson, S. M., Qazi, K. R., Filen, J. J., Lahesmaa, R., Norman, M., et al. (2007). Exosomes with immune modulatory features are present in human breast milk. J. Immunol. 179, 1969-1978. doi: 10.4049/jimmunol.179.3.1969

Akers, J. C., Gonda, D., Kim, R., Carter, B. S., and Chen, C. C. (2013). Biogenesis of extracellular vesicles (EV): exosomes, microvesicles, retrovirus-like vesicles, and apoptotic bodies. J. Neurooncol. 113, 1-11. doi: 10.1007/s11060-013-1084-8

Alique, M., Ruiz-Torres, M. P., Bodega, G., Noci, M. V., Troyano, N., Bohorquez, L., et al. (2017). Microvesicles from the plasma of elderly subjects and from senescent endothelial cells promote vascular calcification. Aging 9, 778-789. doi: 10.18632/aging.101191

Alvarez, M. L., Khosroheidari, M., Kanchi Ravi, R., and Distefano, J. K. (2012). Comparison of protein, microRNA, and mRNA yields using different methods of urinary exosome isolation for the discovery of kidney disease biomarkers. Kidney Int. 82, 1024-1032. doi: 10.1038/ki.2012.256

Atkin-Smith, G. K., Tixeira, R., Paone, S., Mathivanan, S., Collins, C., Liem, M., et al. (2015). A novel mechanism of generating extracellular vesicles during apoptosis via a beads-on-a-string membrane structure. Nat. Commun. 6:7439.

Baek, R., Varming, K., and Jorgensen, M. M. (2016). Does smoking, age or gender affect the protein phenotype of extracellular vesicles in plasma? Transfus. Apher. Sci. 55, 44-52. doi: 10.1016/j.transci.2016.07.012

Baietti, M. F., Zhang, Z., Mortier, E., Melchior, A., Degeest, G., Geeraerts, A., et al. (2012). Syndecan-syntenin-ALIX regulates the biogenesis of exosomes. Nat. Cell Biol. 14, 677-685. doi: 10.1038/ncb2502 have focused on the development of EVs. Advances in the understanding of EVs in recent years have provided remarkable revelations. The relationship between EVs and aging as well as reproductive diseases has attention widespread attention. EVs could have the potential to be a new and non-invasive marker for assessing the condition of aging and reproductive diseases. In-depth research on the role and mechanism of EVs will provide new strategies for delaying aging and treating reproductive diseases and may eventually provide major innovations in their diagnosis and treatment. While EVs have shown potential importance and significance, stronger evidence is needed to support the possibility of EVs as clinical application. In addition, the lack of a gold standard method for EV separation and purification is a challenge and will limit the possibilities and significance of subsequent functional research.

\section{AUTHOR CONTRIBUTIONS}

YL carried out literature search, data collection and analysis, and wrote the manuscript. QS revised the manuscript. LZ carried out design and revised the manuscript. WX took part in design and revised the manuscript. All authors read and approved the manuscript.

\section{FUNDING}

This work was supported by the National Natural Science Foundation of China (NSFC 81871221).

Ballester, M., Santulli, P., Bazot, M., Coutant, C., Rouzier, R., and Darai, E. (2011). Preoperative evaluation of posterior deep-infiltrating endometriosis demonstrates a relationship with urinary dysfunction and parametrial involvement. J. Minim. Invasive Gynecol. 18, 36-42. doi: 10.1016/j.jmig.2010. 08.692

Bertoldi, K., Cechinel, L. R., Schallenberger, B., Corssac, G. B., Davies, S., Guerreiro, I. C. K., et al. (2018). Circulating extracellular vesicles in the aging process: impact of aerobic exercise. Mol. Cell. Biochem. 440, 115-125. doi: 10.1007/ s11010-017-3160-4

Bobrie, A., Colombo, M., Krumeich, S., Raposo, G., and Thery, C. (2012). Diverse subpopulations of vesicles secreted by different intracellular mechanisms are present in exosome preparations obtained by differential ultracentrifugation. J. Extracell. Vesicles 1:18397. doi: 10.3402/jev.v1i0.18397

Boilard, E., Nigrovic, P. A., Larabee, K., Watts, G. F., Coblyn, J. S., Weinblatt, M. E., et al. (2010). Platelets amplify inflammation in arthritis via collagen-dependent microparticle production. Science 327, 580-583. doi: 10.1126/science.1181928

Boing, A. N., Van Der Pol, E., Grootemaat, A. E., Coumans, F. A., Sturk, A., and Nieuwland, R. (2014). Single-step isolation of extracellular vesicles by sizeexclusion chromatography. J. Extracel. Vesicles 3:23430. doi: 10.3402/jev.v3. 23430

Bozdag, G., Mumusoglu, S., Zengin, D., Karabulut, E., and Yildiz, B. O. (2016). The prevalence and phenotypic features of polycystic ovary syndrome: a systematic review and meta-analysis. Hum. Reprod. 31, 2841-2855. doi: 10.1093/humrep/ dew 218

Braidy, N., Guillemin, G. J., Mansour, H., Chan-Ling, T., Poljak, A., and Grant, R. (2011). Age related changes in NAD+ metabolism oxidative stress and Sirt1 activity in wistar rats. PLoS One 6:e19194. doi: 10.1371/journal.pone. 0019194 
Buzas, E. I., Gyorgy, B., Nagy, G., Falus, A., and Gay, S. (2014). Emerging role of extracellular vesicles in inflammatory diseases. Nat. Rev. Rheumatol. 10, 356-364. doi: 10.1038/nrrheum.2014.19

Caby, M. P., Lankar, D., Vincendeau-Scherrer, C., Raposo, G., and Bonnerot, C. (2005). Exosomal-like vesicles are present in human blood plasma. Int. Immunol. 17, 879-887. doi: 10.1093/intimm/dxh267

Campisi, J., and d'Adda di Fagagna, F. (2007). Cellular senescence: when bad things happen to good cells. Nat. Rev. Mol. Cell Biol. 8, 729-740. doi: 10.1038/nrm 2233

Canto, C., Menzies, K. J., and Auwerx, J. (2015). NAD(+) metabolism and the control of energy homeostasis: a balancing act between mitochondria and the nucleus. Cell Metab. 22, 31-53. doi: 10.1016/j.cmet.2015.05.023

Carvalho, L. M. L., Ferreira, C. N., Candido, A. L., Reis, F. M., Soter, M. O., Sales, M. F., et al. (2017a). Metformin reduces total microparticles and microparticlesexpressing tissue factor in women with polycystic ovary syndrome. Arch. Gynecol. Obstet. 296, 617-621. doi: 10.1007/s00404-017-4471-0

Carvalho, L. M. L., Ferreira, C. N., Soter, M. O., Sales, M. F., Rodrigues, K. F., Martins, S. R., et al. (2017b). Microparticles: inflammatory and haemostatic biomarkers in polycystic ovary syndrome. Mol. Cell. Endocrinol. 443, 155-162. doi: 10.1016/j.mce.2017.01.017

Chaput, N., and Thery, C. (2011). Exosomes: immune properties and potential clinical implementations. Semin. Immunopathol. 33, 419-440. doi: 10.1007/ s00281-010-0233-9

Chen, X., Gao, C., Li, H., Huang, L., Sun, Q., Dong, Y., et al. (2010). Identification and characterization of microRNAs in raw milk during different periods of lactation, commercial fluid, and powdered milk products. Cell Res. 20, 11281137. doi: $10.1038 / \mathrm{cr} .2010 .80$

Chen, G. Y., and Nunez, G. (2010). Sterile inflammation: sensing and reacting to damage. Nat. Rev. Immunol. 10, 826-837. doi: 10.1038/nri2873

Choi, D. S., Park, J. O., Jang, S. C., Yoon, Y. J., Jung, J. W., Choi, D. Y., et al. (2011). Proteomic analysis of microvesicles derived from human colorectal cancer ascites. Proteomics 11, 2745-2751. doi: 10.1002/pmic.201100022

Colombo, M., Moita, C., Van Niel, G., Kowal, J., Vigneron, J., Benaroch, P., et al. (2013). Analysis of ESCRT functions in exosome biogenesis, composition and secretion highlights the heterogeneity of extracellular vesicles. J. Cell Sci. 126, 5553-5565. doi: $10.1242 /$ jcs. 128868

Colombo, M., Raposo, G., and Thery, C. (2014). Biogenesis, secretion, and intercellular interactions of exosomes and other extracellular vesicles. Annu. Rev. Cell Dev. Biol. 30, 255-289. doi: 10.1146/annurev-cellbio-101512-122326

Cramer, D. W., and Missmer, S. A. (2002). The epidemiology of endometriosis. Ann. N. Y. Acad. Sci. 955, 11-22; discussion 34-36, 396-406.

Cvjetkovic, A., Lotvall, J., and Lasser, C. (2014). The influence of rotor type and centrifugation time on the yield and purity of extracellular vesicles. J. Extracell. Vesicles 3:23111. doi: 10.3402/jev.v3.23111

da Silveira, J. C., Veeramachaneni, D. N., Winger, Q. A., Carnevale, E. M., and Bouma, G. J. (2012). Cell-secreted vesicles in equine ovarian follicular fluid contain miRNAs and proteins: a possible new form of cell communication within the ovarian follicle. Biol. Reprod. 86:71.

Davis, C., Dukes, A., Drewry, M., Helwa, I., Johnson, M. H., Isales, C. M., et al. (2017). MicroRNA-183-5p increases with age in bone-derived extracellular vesicles, suppresses bone marrow stromal (stem) cell proliferation, and induces stem cell senescence. Tissue Eng. Part A 23, 1231-1240. doi: 10.1089/ten.tea. 2016.0525

Deatherage, B. L., and Cookson, B. T. (2012). Membrane vesicle release in bacteria, eukaryotes, and archaea: a conserved yet underappreciated aspect of microbial life. Infect. Immun. 80, 1948-1957. doi: 10.1128/iai.06014-11

Di Leonardo, A., Linke, S. P., Clarkin, K., and Wahl, G. M. (1994). DNA damage triggers a prolonged p53-dependent G1 arrest and long-term induction of Cip1 in normal human fibroblasts. Genes Dev. 8, 2540-2551. doi: 10.1101/gad.8.21. 2540

Eitan, E., Green, J., Bodogai, M., Mode, N. A., Baek, R., Jorgensen, M. M., et al. (2017). Age-related changes in plasma extracellular vesicle characteristics and internalization by leukocytes. Sci. Rep. 7:1342.

Fadok, V. A., Bratton, D. L., and Henson, P. M. (2001). Phagocyte receptors for apoptotic cells: recognition, uptake, and consequences. J. Clin. Invest. 108, 957-962. doi: 10.1172/jci200114122

Franceschi, C., Bonafe, M., Valensin, S., Olivieri, F., De Luca, M., Ottaviani, E., et al. (2000). Inflamm-aging. An evolutionary perspective on immunosenescence.
Ann. N. Y. Acad. Sci. 908, 244-254. doi: 10.1111/j.1749-6632.2000. tb06651.x

Friedl, P., Vischer, P., and Freyberg, M. A. (2002). The role of thrombospondin-1 in apoptosis. Cell. Mol. Life Sci. 59, 1347-1357. doi: 10.1007/s00018-002-8512-9

Gasparello, J., Lomazzi, M., Papi, C., D’aversa, E., Sansone, F., Casnati, A., et al. (2019). Efficient delivery of MicroRNA and AntimiRNA molecules using an argininocalix[4] arene macrocycle. Mol. Ther. Nucleic Acids 18, 748-763. doi: 10.1016/j.omtn.2019.09.029

Gems, D., and Partridge, L. (2013). Genetics of longevity in model organisms: debates and paradigm shifts. Annu. Rev. Physiol. 75, 621-644. doi: 10.1146/ annurev-physiol-030212-183712

Giudice, L. C. (2010). Clinical practice. Endometriosis. N. Engl. J. Med. 362, 2389-2398.

Gomes, A. P., Price, N. L., Ling, A. J., Moslehi, J. J., Montgomery, M. K., Rajman, L., et al. (2013). Declining $\mathrm{NAD}(+)$ induces a pseudohypoxic state disrupting nuclear-mitochondrial communication during aging. Cell 155, 1624-1638. doi: 10.1016/j.cell.2013.11.037

Gomes de Andrade, G., Reck Cechinel, L., Bertoldi, K., Galvao, F., Valdeci Worm, P., and Rodrigues Siqueira, I. (2018). The aging process alters IL-1beta and CD63 levels differently in extracellular vesicles obtained from the plasma and cerebrospinal fluid. Neuroimmunomodulation 25, 18-22. doi: 10.1159/ 000488943

Gonzales, P. A., Pisitkun, T., Hoffert, J. D., Tchapyjnikov, D., Star, R. A., Kleta, R., et al. (2009). Large-scale proteomics and phosphoproteomics of urinary exosomes. J. Am. Soc. Nephrol. 20, 363-379. doi: 10.1681/asn.2008040406

Gordts, S., Puttemans, P., Gordts, S., and Brosens, I. (2015). Ovarian endometrioma in the adolescent: a plea for early-stage diagnosis and full surgical treatment. Gynecol. Surg. 12, 21-30. doi: 10.1007/s10397-014-0877-x

Goswami, B., Rajappa, M., Sharma, M., and Sharma, A. (2008). Inflammation: its role and interplay in the development of cancer, with special focus on gynecological malignancies. Int. J. Gynecol. Cancer 18, 591-599. doi: 10.1111/j. 1525-1438.2007.01089.x

Greening, D. W., Xu, R., Ji, H., Tauro, B. J., and Simpson, R. J. (2015). A protocol for exosome isolation and characterization: evaluation of ultracentrifugation, density-gradient separation, and immunoaffinity capture methods. Methods Mol. Biol. 1295, 179-209. doi: 10.1007/978-1-4939-2550-6_15

Gupta, S., Goldberg, J. M., Aziz, N., Goldberg, E., Krajcir, N., and Agarwal, A. (2008). Pathogenic mechanisms in endometriosis-associated infertility. Fertil. Steril. 90, 247-257. doi: 10.1016/j.fertnstert.2008.02.093

Gyorgy, B., Szabo, T. G., Pasztoi, M., Pal, Z., Misjak, P., Aradi, B., et al. (2011). Membrane vesicles, current state-of-the-art: emerging role of extracellular vesicles. Cell. Mol. Life Sci. 68, 2667-2688. doi: 10.1007/s00018-011-0689-3

Harp, D., Driss, A., Mehrabi, S., Chowdhury, I., Xu, W., Liu, D., et al. (2016). Exosomes derived from endometriotic stromal cells have enhanced angiogenic effects in vitro. Cell Tissue Res. 365, 187-196. doi: 10.1007/s00441-016-2358-1

Hartlova, A., Erttmann, S. F., Raffi, F. A., Schmalz, A. M., Resch, U., Anugula, S., et al. (2015). DNA damage primes the type I interferon system via the cytosolic DNA sensor STING to promote anti-microbial innate immunity. Immunity 42, 332-343. doi: 10.1016/j.immuni.2015.01.012

Hartman, Z. C., Wei, J., Glass, O. K., Guo, H., Lei, G., Yang, X. Y., et al. (2011). Increasing vaccine potency through exosome antigen targeting. Vaccine 29, 9361-9367. doi: 10.1016/j.vaccine.2011.09.133

Helwa, I., Cai, J., Drewry, M. D., Zimmerman, A., Dinkins, M. B., Khaled, M. L., et al. (2017). A comparative study of serum exosome isolation using differential ultracentrifugation and three commercial reagents. PLoS One 12:e0170628. doi: 10.1371/journal.pone.0170628

Herbig, U., Jobling, W. A., Chen, B. P., Chen, D. J., and Sedivy, J. M. (2004). Telomere shortening triggers senescence of human cells through a pathway involving ATM, p53, and p21(CIP1), but not p16(INK4a). Mol. Cell 14, 501513. doi: 10.1016/s1097-2765(04)00256-4

Hristov, M., Erl, W., Linder, S., and Weber, P. C. (2004). Apoptotic bodies from endothelial cells enhance the number and initiate the differentiation of human endothelial progenitor cells in vitro. Blood 104, 2761-2766. doi: 10.1182/blood2003-10-3614

Jakobsen, K. R., Paulsen, B. S., Baek, R., Varming, K., Sorensen, B. S., and Jorgensen, M. M. (2015). Exosomal proteins as potential diagnostic markers in advanced non-small cell lung carcinoma. J. Extracell. Vesicles 4:26659. doi: 10.3402/jev. v4.26659 
Jeppesen, D. K., Fenix, A. M., Franklin, J. L., Higginbotham, J. N., Zhang, Q., Zimmerman, L. J., et al. (2019). Reassessment of exosome composition. Cell 177, 428-445.e18.

Jeppesen, D. K., Hvam, M. L., Primdahl-Bengtson, B., Boysen, A. T., Whitehead, B., Dyrskjot, L., et al. (2014). Comparative analysis of discrete exosome fractions obtained by differential centrifugation. J. Extracell. Vesicles 3:25011. doi: 10. 3402/jev.v3.25011

Khalaj, K., Miller, J. E., Lingegowda, H., Fazleabas, A. T., Young, S. L., Lessey, B. A., et al. (2019). Extracellular vesicles from endometriosis patients are characterized by a unique miRNA-lncRNA signature. JCI Insight 4:e128846.

Khan, N. A., Auranen, M., Paetau, I., Pirinen, E., Euro, L., Forsstrom, S., et al. (2014). Effective treatment of mitochondrial myopathy by nicotinamide riboside, a vitamin B3. EMBO Mol. Med. 6, 721-731. doi: 10.1002/emmm. 201403943

Khayrullin, A., Krishnan, P., Martinez-Nater, L., Mendhe, B., Fulzele, S., Liu, Y., et al. (2019). Very long-chain C24:1 ceramide is increased in serum extracellular vesicles with aging and can induce senescence in bone-derived mesenchymal stem cells. Cells 8:37. doi: 10.3390/cells 8010037

Kirkwood, T. B. (2005). Understanding the odd science of aging. Cell 120,437-447. doi: 10.1016/j.cell.2005.01.027

Koga, H., Sugiyama, S., Kugiyama, K., Watanabe, K., Fukushima, H., Tanaka, T., et al. (2005). Elevated levels of VE-cadherin-positive endothelial microparticles in patients with type 2 diabetes mellitus and coronary artery disease. J. Am. Coll. Cardiol. 45, 1622-1630. doi: 10.1016/j.jacc.2005.02.047

Koiou, E., Tziomalos, K., Katsikis, I., Papadakis, E., Kandaraki, E. A., and Panidis, D. (2013). Platelet-derived microparticles in overweight/obese women with the polycystic ovary syndrome. Gynecol. Endocrinol. 29, 250-253. doi: 10.3109/ 09513590.2012.743005

Kowal, J., Arras, G., Colombo, M., Jouve, M., Morath, J. P., Primdal-Bengtson, B., et al. (2016). Proteomic comparison defines novel markers to characterize heterogeneous populations of extracellular vesicle subtypes. Proc. Natl. Acad. Sci. U.S.A. 113, E968-E977.

Kyselova, A., Hinrichsmeyer, H., Zukunft, S., Mann, A. W., Dornauf, I., Fleming, I., et al. (2019). Association between arginase-containing platelet-derived microparticles and altered plasma arginine metabolism in polycystic ovary syndrome. Metabolism 90, 16-19. doi: 10.1016/j.metabol.2018.10.008

Landi, F., Calvani, R., Cesari, M., Tosato, M., Martone, A. M., Ortolani, E., et al. (2018). Sarcopenia: an overview on current definitions, diagnosis and treatment. Curr. Protein Pept. Sci. 19, 633-638. doi: 10.2174/ 1389203718666170607113459

Law, B. A., Liao, X., Moore, K. S., Southard, A., Roddy, P., Ji, R., et al. (2018). Lipotoxic very-long-chain ceramides cause mitochondrial dysfunction, oxidative stress, and cell death in cardiomyocytes. FASEB J. 32, 1403-1416. doi: 10.1096/fj.201700300r

Lehmann, B. D., Paine, M. S., Brooks, A. M., Mccubrey, J. A., Renegar, R. H., Wang, R., et al. (2008). Senescence-associated exosome release from human prostate cancer cells. Cancer Res. 68, 7864-7871. doi: 10.1158/0008-5472.can-07-6538

Li, H., Huang, X., Chang, X., Yao, J., He, Q., Shen, Z., et al. (2019). S100-A9 protein in exosomes derived from follicular fluid promotes inflammation via activation of NF-kappaB pathway in polycystic ovary syndrome. J. Cell. Mol. Med. 24, 114-125. doi: $10.1111 /$ jcmm. 14642

Li, J., Sherman-Baust, C. A., Tsai-Turton, M., Bristow, R. E., Roden, R. B., and Morin, P. J. (2009). Claudin-containing exosomes in the peripheral circulation of women with ovarian cancer. BMC Cancer 9:244. doi: 10.1186/1471-24079-244

Lin, J. B., Kubota, S., Mostoslavsky, R., and Apte, R. S. (2018). Role of sirtuins in retinal function under basal conditions. Adv. Exp. Med. Biol. 1074, 561-567. doi: 10.1007/978-3-319-75402-4_68

Liu, S., Mahairaki, V., Bai, H., Ding, Z., Li, J., Witwer, K. W., et al. (2019). Highly purified human extracellular vesicles produced by stem cells alleviate aging cellular phenotypes of senescent human cells. Stem Cells 37, 779-790. doi: 10.1002/stem.2996

Lugli, G., Cohen, A. M., Bennett, D. A., Shah, R. C., Fields, C. J., Hernandez, A. G., et al. (2015). Plasma exosomal miRNAs in persons with and without Alzheimer disease: altered expression and prospects for biomarkers. PLoS One 10:e0139233. doi: 10.1371/journal.pone.0139233
Machida, T., Tomofuji, T., Ekuni, D., Maruyama, T., Yoneda, T., Kawabata, Y., et al. (2015). MicroRNAs in salivary exosome as potential biomarkers of aging. Int. J. Mol. Sci. 16, 21294-21309. doi: 10.3390/ijms160921294

Malutan, A. M., Drugan, T., Costin, N., Ciortea, R., Bucuri, C., Rada, M. P., et al. (2015). Pro-inflammatory cytokines for evaluation of inflammatory status in endometriosis. Cent. Eur. J. Immunol. 40, 96-102. doi: 10.5114/ceji.2015.50840

Marques, F. K., Campos, F. M., Sousa, L. P., Teixeira-Carvalho, A., Dusse, L. M., and Gomes, K. B. (2013). Association of microparticles and preeclampsia. Mol. Biol. Rep. 40, 4553-4559.

Mathieu, M., Martin-Jaular, L., Lavieu, G., and Thery, C. (2019). Specificities of secretion and uptake of exosomes and other extracellular vesicles for cellto-cell communication. Nat. Cell Biol. 21, 9-17. doi: 10.1038/s41556-0180250-9

Mathivanan, S., Ji, H., and Simpson, R. J. (2010). Exosomes: extracellular organelles important in intercellular communication. J. Proteomics 73, 1907-1920. doi: 10.1016/j.jprot.2010.06.006

Matsuzaki, S., and Darcha, C. (2014). Antifibrotic properties of epigallocatechin-3gallate in endometriosis. Hum. Reprod. 29, 1677-1687. doi: 10.1093/humrep/ deu123

Matsuzaki, S., Darcha, C., Maleysson, E., Canis, M., and Mage, G. (2010). Impaired down-regulation of E-cadherin and beta-catenin protein expression in endometrial epithelial cells in the mid-secretory endometrium of infertile patients with endometriosis. J. Clin. Endocrinol. Metab. 95, 3437-3445. doi: 10.1210/jc.2009-2713

Mesri, M., and Altieri, D. C. (1998). Endothelial cell activation by leukocyte microparticles. J. Immunol. 161, 4382-4387.

Mitchell, P. J., Welton, J., Staffurth, J., Court, J., Mason, M. D., Tabi, Z., et al. (2009). Can urinary exosomes act as treatment response markers in prostate cancer? J. Transl. Med. 7:4. doi: 10.1186/1479-5876-7-4

Mobarak, H., Heidarpour, M., Lolicato, F., Nouri, M., Rahbarghazi, R., and Mahdipour, M. (2019). Physiological impact of extracellular vesicles on female reproductive system; highlights to possible restorative effects on female age-related fertility. Biofactors 45, 293-303. doi: 10.1002/biof. 1497

Mooberry, M. J., Bradford, R., Hobl, E. L., Lin, F. C., Jilma, B., and Key, N. S. (2016). Procoagulant microparticles promote coagulation in a factor XI-dependent manner in human endotoxemia. J. Thromb. Haemost. 14, 1031-1042. doi: $10.1111 /$ jth.13285

Mouchiroud, L., Houtkooper, R. H., Moullan, N., Katsyuba, E., Ryu, D., Canto, C., et al. (2013). The NAD(+)/sirtuin pathway modulates longevity through activation of mitochondrial UPR and FOXO signaling. Cell 154, 430-441. doi: 10.1016/j.cell.2013.06.016

Munros, J., Martinez-Zamora, M. A., Tassies, D., Coloma, J. L., Torrente, M. A., Reverter, J. C., et al. (2017). Total circulating microparticle levels are increased in patients with deep infiltrating endometriosis. Hum. Reprod. 32, 325-331. doi: 10.1093/humrep/dew319

Muralidharan-Chari, V., Clancy, J., Plou, C., Romao, M., Chavrier, P., Raposo, G., et al. (2009). ARF6-regulated shedding of tumor cell-derived plasma membrane microvesicles. Curr. Biol. 19, 1875-1885. doi: 10.1016/j.cub.2009. 09.059

Muth, D. C., Mcalexander, M. A., Ostrenga, L. J., Pate, N. M., Izzi, J. M., Adams, R. J., et al. (2015). Potential role of cervicovaginal extracellular particles in diagnosis of endometriosis. BMC Vet. Res. 11:187. doi: 10.1186/s12917-0150513-7

Nehir Aytan, A., Bastu, E., Demiral, I., Bulut, H., Dogan, M., and Buyru, F. (2016). Relationship between hyperandrogenism, obesity, inflammation and polycystic ovary syndrome. Gynecol. Endocrinol. 32, 709-713. doi: 10.3109/09513590. 2016.1155208

Nomura, S., and Shimizu, M. (2015). Clinical significance of procoagulant microparticles. J. Intensive Care 3:2. doi: 10.1186/s40560-014-0066-Z

Ogawa, Y., Kanai-Azuma, M., Akimoto, Y., Kawakami, H., and Yanoshita, R. (2008). Exosome-like vesicles with dipeptidyl peptidase IV in human saliva. Biol. Pharm. Bull. 31, 1059-1062. doi: 10.1248/bpb.31.1059

Ostergaard, O., Nielsen, C. T., Iversen, L. V., Tanassi, J. T., Knudsen, S., Jacobsen, S., et al. (2013). Unique protein signature of circulating microparticles in systemic lupus erythematosus. Arthritis Rheum. 65, 2680-2690. 
Ostrowski, M., Carmo, N. B., Krumeich, S., Fanget, I., Raposo, G., Savina, A., et al. (2010). Rab27a and Rab27b control different steps of the exosome secretion pathway. Nat. Cell Biol. 12, 19-30. doi: 10.1038/ncb2000

Palomba, S., Santagni, S., Falbo, A., and La Sala, G. B. (2015). Complications and challenges associated with polycystic ovary syndrome: current perspectives. Int. J. Womens Health 7, 745-763. doi: 10.2147/ijwh.s70314

Parks, J. C., Mccallie, B. R., Patton, A. L., Al-Safi, Z. A., Polotsky, A. J., Griffin, D. K., et al. (2018). The impact of infertility diagnosis on embryo-endometrial dialogue. Reproduction 155, 543-552. doi: 10.1530/REP-17-0566

Paul Dmowski, W., and Braun, D. P. (2004). Immunology of endometriosis. Best Pract. Res. Clin. Obstet. Gynaecol. 18, 245-263.

Prado, N., Marazuela, E. G., Segura, E., Fernandez-Garcia, H., Villalba, M., Thery, C., et al. (2008). Exosomes from bronchoalveolar fluid of tolerized mice prevent allergic reaction. J. Immunol. 181, 1519-1525. doi: 10.4049/jimmunol.181.2. 1519

Pusic, A. D., and Kraig, R. P. (2014). Youth and environmental enrichment generate serum exosomes containing miR-219 that promote CNS myelination. Glia 62, 284-299. doi: 10.1002/glia.22606

Qiu, J. J., Lin, X. J., Zheng, T. T., Tang, X. Y., Zhang, Y., and Hua, K. Q. (2019). The exosomal long noncoding RNA aHIF is upregulated in serum from patients with endometriosis and promotes angiogenesis in endometriosis. Reprod. Sci. 26, 1590-1602. doi: 10.1177/1933719119831775

Rajman, L., Chwalek, K., and Sinclair, D. A. (2018). Therapeutic potential of NADboosting molecules: the in vivo evidence. Cell Metab. 27, 529-547. doi: 10.1016/ j.cmet.2018.02.011

Raposo, G., Nijman, H. W., Stoorvogel, W., Liejendekker, R., Harding, C. V., Melief, C. J., et al. (1996). B lymphocytes secrete antigen-presenting vesicles. J. Exp. Med. 183, 1161-1172. doi: 10.1084/jem.183.3.1161

Raposo, G., and Stoorvogel, W. (2013). Extracellular vesicles: exosomes, microvesicles, and friends. J. Cell Biol. 200, 373-383. doi: 10.1083/jcb. 201211138

Rekker, K., Saare, M., Roost, A. M., Kubo, A. L., Zarovni, N., Chiesi, A., et al. (2014). Comparison of serum exosome isolation methods for microRNA profiling. Clin. Biochem. 47, 135-138. doi: 10.1016/j.clinbiochem.2013.10.020

Repaci, A., Gambineri, A., and Pasquali, R. (2011). The role of low-grade inflammation in the polycystic ovary syndrome. Mol. Cell. Endocrinol. 335, 30-41. doi: 10.1016/j.mce.2010.08.002

Robinson, D. G., Ding, Y., and Jiang, L. (2016). Unconventional protein secretion in plants: a critical assessment. Protoplasma 253, 31-43. doi: 10.1007/s00709015-0887-1

Saman, S., Kim, W., Raya, M., Visnick, Y., Miro, S., Saman, S., et al. (2012). Exosome-associated tau is secreted in tauopathy models and is selectively phosphorylated in cerebrospinal fluid in early Alzheimer disease. J. Biol. Chem. 287, 3842-3849. doi: 10.1074/jbc.m111.277061

Sang, Q., Yao, Z., Wang, H., Feng, R., Wang, H., Zhao, X., et al. (2013). Identification of microRNAs in human follicular fluid: characterization of microRNAs that govern steroidogenesis in vitro and are associated with polycystic ovary syndrome in vivo. J. Clin. Endocrinol. Metab. 98, 3068-3079. doi: 10.1210/jc.2013-1715

Schorey, J. S., Cheng, Y., Singh, P. P., and Smith, V. L. (2015). Exosomes and other extracellular vesicles in host-pathogen interactions. EMBO Rep. 16, 24-43. doi: 10.15252/embr.201439363

Shiels, P. G., Stenvinkel, P., Kooman, J. P., and Mcguinness, D. (2017). Circulating markers of ageing and allostatic load: a slow train coming. Pract. Lab. Med. 7 , 49-54. doi: 10.1016/j.plabm.2016.04.002

Simon, C., Greening, D. W., Bolumar, D., Balaguer, N., Salamonsen, L. A., and Vilella, F. (2018). Extracellular vesicles in human reproduction in health and disease. Endocr. Rev. 39, 292-332. doi: 10.1210/er.2017-00229

Smith, J. A., Leonardi, T., Huang, B., Iraci, N., Vega, B., and Pluchino, S. (2015). Extracellular vesicles and their synthetic analogues in aging and ageassociated brain diseases. Biogerontology 16, 147-185. doi: 10.1007/s10522-0149510-7

Smith-Vikos, T., and Slack, F. J. (2012). MicroRNAs and their roles in aging. J. Cell Sci. 125, 7-17. doi: 10.1242/jcs.099200

Sohel, M. M., Hoelker, M., Noferesti, S. S., Salilew-Wondim, D., Tholen, E., Looft, C., et al. (2013). Exosomal and non-exosomal transport of extra-cellular microRNAs in follicular fluid: implications for bovine oocyte developmental competence. PLoS One 8:e78505. doi: 10.1371/journal.pone.0078505

Stegmayr, B., and Ronquist, G. (1982). Promotive effect on human sperm progressive motility by prostasomes. Urol. Res. 10, 253-257.
Sun, H., Li, D., Yuan, M., Li, Q., Zhen, Q., Li, N., et al. (2019). Macrophages alternatively activated by endometriosis-exosomes contribute to the development of lesions in mice. Mol. Hum. Reprod. 25, 5-16. doi: 10.1093/molehr/gay049

Takahashi, A., Okada, R., Nagao, K., Kawamata, Y., Hanyu, A., Yoshimoto, S., et al. (2017). Exosomes maintain cellular homeostasis by excreting harmful DNA from cells. Nat. Commun. 8:15287.

Takasugi, M., Okada, R., Takahashi, A., Virya Chen, D., Watanabe, S., and Hara, E. (2017). Small extracellular vesicles secreted from senescent cells promote cancer cell proliferation through EphA2. Nat. Commun. 8:15729.

Takizawa, F., Tsuji, S., and Nagasawa, S. (1996). Enhancement of macrophage phagocytosis upon iC3b deposition on apoptotic cells. FEBS Lett. 397, 269-272. doi: 10.1016/s0014-5793(96)01197-0

Tang, Y. T., Huang, Y. Y., Zheng, L., Qin, S. H., Xu, X. P., An, T. X., et al. (2017). Comparison of isolation methods of exosomes and exosomal RNA from cell culture medium and serum. Int. J. Mol. Med. 40, 834-844. doi: 10.3892/ijmm. 2017.3080

Tauro, B. J., Greening, D. W., Mathias, R. A., Ji, H., Mathivanan, S., Scott, A. M., et al. (2012). Comparison of ultracentrifugation, density gradient separation, and immunoaffinity capture methods for isolating human colon cancer cell line LIM1863-derived exosomes. Methods 56, 293-304. doi: 10.1016/j.ymeth.2012. 01.002

Taylor, D. D., Zacharias, W., and Gercel-Taylor, C. (2011). Exosome isolation for proteomic analyses and RNA profiling. Methods Mol. Biol. 728, 235-246. doi: 10.1007/978-1-61779-068-3_15

Teede, H., Deeks, A., and Moran, L. (2010). Polycystic ovary syndrome: a complex condition with psychological, reproductive and metabolic manifestations that impacts on health across the lifespan. BMC Med. 8:41. doi: 10.1186/17417015-8-41

Tricarico, C., Clancy, J., and D'souza-Schorey, C. (2017). Biology and biogenesis of shed microvesicles. Small GTPases 8, 220-232. doi: 10.1080/21541248.2016. 1215283

Urbanelli, L., Buratta, S., Sagini, K., Tancini, B., and Emiliani, C. (2016). Extracellular vesicles as new players in cellular senescence. Int. J. Mol. Sci. 17:1408. doi: 10.3390/ijms17091408

Valadi, H., Ekstrom, K., Bossios, A., Sjostrand, M., Lee, J. J., and Lotvall, J. O. (2007). Exosome-mediated transfer of mRNAs and microRNAs is a novel mechanism of genetic exchange between cells. Nat. Cell Biol. 9, 654-659. doi: 10.1038/ncb1596 van Balkom, B. W., De Jong, O. G., Smits, M., Brummelman, J., Den Ouden, K., De Bree, P. M., et al. (2013). Endothelial cells require miR-214 to secrete exosomes that suppress senescence and induce angiogenesis in human and mouse endothelial cells. Blood 121, 3997-4006, S1-S15.

Van Deun, J., Mestdagh, P., Sormunen, R., Cocquyt, V., Vermaelen, K., Vandesompele, J., et al. (2014). The impact of disparate isolation methods for extracellular vesicles on downstream RNA profiling. J. Extracell. Vesicles 3:24858. doi: $10.3402 /$ jev.v3.24858

van Niel, G., D'angelo, G., and Raposo, G. (2018). Shedding light on the cell biology of extracellular vesicles. Nat. Rev. Mol. Cell Biol. 19, 213-228. doi: 10.1038/nrm.2017.125

Venable, M. E., Lee, J. Y., Smyth, M. J., Bielawska, A., and Obeid, L. M. (1995). Role of ceramide in cellular senescence. J. Biol. Chem. 270, 30701-30708. doi: $10.1074 /$ jbc. 270.51 .30701

Verdin, E. (2015). NAD(+) in aging, metabolism, and neurodegeneration. Science 350, 1208-1213. doi: 10.1126/science.aac4854

Wang, G., Dinkins, M., He, Q., Zhu, G., Poirier, C., Campbell, A., et al. (2012). Astrocytes secrete exosomes enriched with proapoptotic ceramide and prostate apoptosis response 4 (PAR-4): potential mechanism of apoptosis induction in Alzheimer disease (AD). J. Biol. Chem. 287, 21384-21395. doi: 10.1074/jbc. m112.340513

Wei, Z., Batagov, A. O., Schinelli, S., Wang, J., Wang, Y., El Fatimy, R., et al. (2017). Coding and noncoding landscape of extracellular RNA released by human glioma stem cells. Nat. Commun. 8:1145.

Willis, G. R., Connolly, K., Ladell, K., Davies, T. S., Guschina, I. A., Ramji, D., et al. (2014). Young women with polycystic ovary syndrome have raised levels of circulating annexin V-positive platelet microparticles. Hum. Reprod. 29, 2756-2763. doi: 10.1093/humrep/deu281

Witwer, K. W., Buzas, E. I., Bemis, L. T., Bora, A., Lasser, C., Lotvall, J., et al. (2013). Standardization of sample collection, isolation and analysis methods in extracellular vesicle research. J. Extracell. Vesicles 2:20360. doi: 10.3402/jev.v2i0. 20360 
Wu, D., Lu, P., Mi, X., and Miao, J. (2018). Exosomal miR-214 from endometrial stromal cells inhibits endometriosis fibrosis. Mol. Hum. Reprod. 24, 357-365.

Xu, R., Greening, D. W., Rai, A., Ji, H., and Simpson, R. J. (2015). Highly-purified exosomes and shed microvesicles isolated from the human colon cancer cell line LIM1863 by sequential centrifugal ultrafiltration are biochemically and functionally distinct. Methods 87, 11-25. doi: 10.1016/j.ymeth.2015. 04.008

Xu, R., Greening, D. W., Zhu, H. J., Takahashi, N., and Simpson, R. J. (2016). Extracellular vesicle isolation and characterization: toward clinical application. J. Clin. Invest. 126, 1152-1162. doi: 10.1172/jci81129

Xu, R., Shen, X., Si, Y., Fu, Y., Zhu, W., Xiao, T., et al. (2018). MicroRNA-31a$5 \mathrm{p}$ from aging BMSCs links bone formation and resorption in the aged bone marrow microenvironment. Aging Cell 17:e12794. doi: 10.1111/acel.12794

Yanez-Mo, M., Siljander, P. R., Andreu, Z., Zavec, A. B., Borras, F. E., Buzas, E. I., et al. (2015). Biological properties of extracellular vesicles and their physiological functions. J. Extracell. Vesicles 4:27066.

Yoshida, M., Satoh, A., Lin, J. B., Mills, K. F., Sasaki, Y., Rensing, N., et al. (2019). Extracellular vesicle-contained eNAMPT delays aging and extends lifespan in mice. Cell Metab. 30, 329-342.e5.

Yoshino, J., Baur, J. A., and Imai, S. I. (2018). NAD(+) intermediates: the biology and therapeutic potential of NMN and NR. Cell Metab. 27, 513-528. doi: 10.1016/j.cmet.2017.11.002
Zhang, A., Wang, G., Jia, L., Su, T., and Zhang, L. (2019). Exosome-mediated microRNA-138 and vascular endothelial growth factor in endometriosis through inflammation and apoptosis via the nuclear factor-kappaB signaling pathway. Int. J. Mol. Med. 43, 358-370.

Zhao, Y., Tao, M., Wei, M., Du, S., Wang, H., and Wang, X. (2019). Mesenchymal stem cells derived exosomal miR-323-3p promotes proliferation and inhibits apoptosis of cumulus cells in polycystic ovary syndrome (PCOS). Artif. Cells Nanomed. Biotechnol. 47, 3804-3813. doi: 10.1080/21691401.2019.1669619

Zitvogel, L., Regnault, A., Lozier, A., Wolfers, J., Flament, C., Tenza, D., et al. (1998). Eradication of established murine tumors using a novel cell-free vaccine: dendritic cell-derived exosomes. Nat. Med. 4, 594-600. doi: 10.1038/ nm0598-594

Conflict of Interest: The authors declare that the research was conducted in the absence of any commercial or financial relationships that could be construed as a potential conflict of interest.

Copyright (c) $2020 \mathrm{Liu}$, Shen, Zhang and Xiang. This is an open-access article distributed under the terms of the Creative Commons Attribution License (CC BY). The use, distribution or reproduction in other forums is permitted, provided the original author(s) and the copyright owner(s) are credited and that the original publication in this journal is cited, in accordance with accepted academic practice. No use, distribution or reproduction is permitted which does not comply with these terms. 